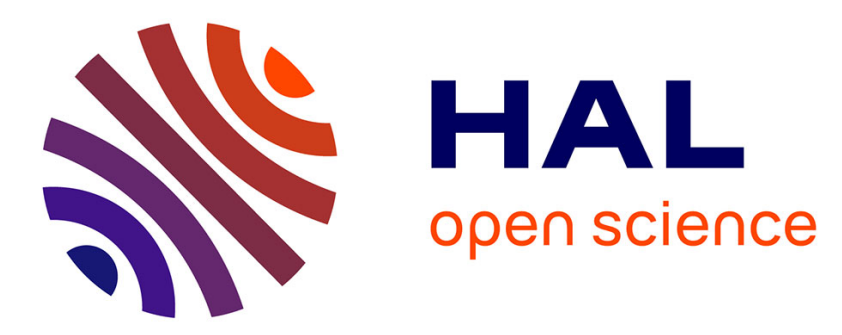

\title{
Severe neonatal seizures: From molecular diagnosis to precision therapy?
}

Mathieu Milh, Pierre Cacciagli, Cecile Mignon-Ravix, Catherine Badens, A. Lepine, N. Villeneuve, Laurent Villard

\section{- To cite this version:}

Mathieu Milh, Pierre Cacciagli, Cecile Mignon-Ravix, Catherine Badens, A. Lepine, et al.. Severe neonatal seizures: From molecular diagnosis to precision therapy?. Revue Neurologique, 2016, 172 (3), pp.171-173. 10.1016/j.neurol.2016.02.005 . hal-01668113

\section{HAL Id: hal-01668113 \\ https://hal-amu.archives-ouvertes.fr/hal-01668113}

Submitted on 19 Dec 2017

HAL is a multi-disciplinary open access archive for the deposit and dissemination of scientific research documents, whether they are published or not. The documents may come from teaching and research institutions in France or abroad, or from public or private research centers.
L'archive ouverte pluridisciplinaire HAL, est destinée au dépôt et à la diffusion de documents scientifiques de niveau recherche, publiés ou non, émanant des établissements d'enseignement et de recherche français ou étrangers, des laboratoires publics ou privés. 


\title{
Severe neonatal seizures: From molecular diagnosis to precision therapy?
}

\author{
M. Milh, P. Cacciagli, C. Ravix, C. Badens, A. Lépine, N. Villeneuve, L. Villard \\ Aix-Marseille Université, Inserm, Service de neurologie pédiatrique, GMGF UMR_S 910, 264, rue Saint-Pierre, \\ 13385 Marseille, France
}

\begin{abstract}
A B S T R A C T
Early onset epileptic encephalopathies (EOEE) are heterogeneous group of severe epilepsies that still need to be better defined and characterized. On a genetic point of view, several dozen of genes have been associated with EOEE, and to date, it is difficult to find a common mechanism to explain EOEE. In this short review, we show that two mains genes are involved in EOEE: STXBP1 and KCNQ2. Focusing on KCNQ2 related EOEE, we show that a relatively similar phenotype can be related to various consequences of mutations on a single gene. This will probably challenge the treatment of EOEE patients.
\end{abstract}

\section{Introduction}

Early epileptic encephalopathies (EEE) are a heterogeneous group of diseases characterized by the association of severe epilepsy and permanent abnormal neurological examination, as part of a developmental disorder. These are serious diseases, with severe prognosis in terms of neurological disability. Given the early and immediately severe nature of epilepsy, it is very difficult to determine whether the developmental disorder is secondary to seizure activity (seizures and interictal activities) or to genetic abnormality by itself (mutation in an ion channel, for example). So, the term of epileptic encephalopathy is probably used by excess, at least in some cases [1]. Currently, the vast majority of EEE is incurable. The AED has a greater or lesser effect on seizure frequency, but do not change drastically the long-term prognosis, apart from rare exceptions. The causes of the EEE are heterogeneous, but most of them are probably genetic, with an MRI not presenting any structural abnormalities that can explain it. Currently, several dozen of genes were involved in the EEE [2]. Here we will describe the phenotype associated to the most frequently mutated genes found in the EEE, and we will question the usefulness of finding a mutation in the therapeutic strategy.

\section{Relative frequency of different EEE genes: results of a prospective study of 63 patients with a severe epilepsy beginning before 3 months followed in Marseille}

In order to assess the relative frequency of major genes of EEE, we have prospectively studied a total of 70 patients with EEE, 


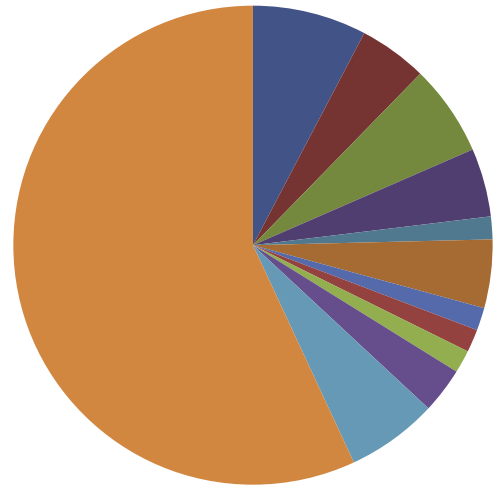

- KCNQ2

- STXBP1

- SCN8A

- KCNT1

$\because \mathrm{SCN} 2 \mathrm{~A}$

- TBC1D24

- ARX

- SLC13A5

KCNQ3

a aCGH

- Other causes

- Unknown

Fig. 1 - Genetic analysis of 70 patients with EEE.

and tested several genes (Fig. 1). By definition, epilepsy began before 3 months and MRI did not find obvious structural cause of this epilepsy. Patients were tested for STXBP1, KCNQ2, KCNQ3, SCN2A, SCN8A, KCNT1, ARX, SLC13A5. They all had CGH array.

No mutation of these genes has been found in 37/ 63 patients. The most frequently mutated gene was KCNQ2 (5/70, $8 \%)$, followed by SCN8A (4/70, $6 \%)$, STXBP1 (3/70, $5 \%)$, KCNT1 (3/70, $5 \%$ ), TBC1D24 (3/70, $3 \%)$. We found one mutation of ARX, SLC13A5, SCN2A and KCNQ3 (1/70). In 2 patients, an abnormality in CGH allowed to explain the EEE. Four patients were carrying a mutation in other genes. Overall, the most frequently mutated genes found in our cohort were KCNQ2, STXBP1, SCN8A and KCNT1.

The majority of patients EEE did not, however, carry any abnormality in the genes that we tested.

This study put the light on two major genes of EEE: STXBP1 and KCNQ2 (Fig. 2). The key features of STXBP1 and KCNQ2 related epilepsies were:

- for KCNQ2: very early onset (first week); out of hand very frequent tonic asymmetric seizures with blockpnea and cyanosis, interictal EEG either discontinuous or showing a

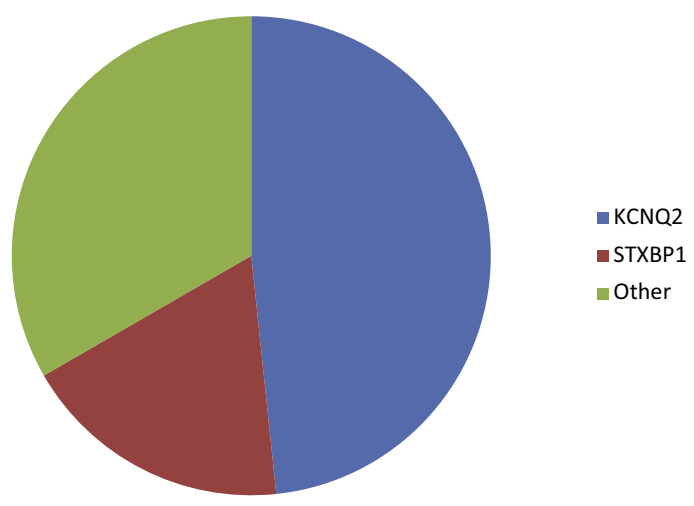

Fig. 2 - Relative proportion of KCNQ2 and STXBP1 mutations in a cohort of 60 patients with an Ohtahara syndrome. Sixty patients with an Ohathara syndrome were tested for KCNQ2 and STXBP1. The cohort was built with patients' DNA, coming from several centers of France, with a diagnosis of Ohtahara Syndrome.

suppression-burst pattern, no or poor efficacy of Phenobarbital [3];

- for STXBP1: onset within the first three months of life, mostly during the first month, motor seizures but less frequent and better tolerated, often focal. Interictal EEG showing either a discontinuity (50\%) or focal spikes [4]. In a specific retrospective cohort of patients with an Ohathara syndrome, the rate of mutation of these two genes was high (see above).

\section{Targeted therapy trials}

The recent advances in gene discovery lead to the generation of various dedicated animal models aimed to find pathophysiological hypothesis that could explain the epilepsy and/or the developmental impairment. Functional studies made at different levels (cellular, neuronal, network, entire animal model) could also lead to the discovery of potential targets and treatments that could correct a biological effect of a specific mutation. Here, we will deal only with therapies that have been proposed/developed after the discovery of the gene involved in epilepsy, as part of a translational research program. Numerous targeted therapies from clinical research such stiripentol in Dravet syndrome, or vitamin B6 in the mutation of the Antiquitin are excluded from this presentation.

We will discuss three recent examples of targeted therapy, data from research on animals models: RETIGABINE and KCNQ2 mutations; QUINIDINE and mutations of KCNT1 and ARX and CDKL5.

\subsection{Retigabine and KCNQ2 mutations}

Retigabine acts as an activator of neuron-expressed KCNQchannels, thereby reducing neuronal excitability. Patients with a KCNQ2 mediated epileptic encephalopathy may especially benefit from this targeted therapy, as rapid control of seizures could potentially improve developmental outcome. Specific clinical studies are still needed to test this hypothesis. Electrophysiological analysis on xenopus oocytes or on CHO cells showed that the majority of KCNQ2 mutations lead to a measurable effect on potassium current, at the sub threshold level at which these channels are known to critically influence neuronal firing, either by globally reducing current amplitudes or by a depolarizing shift of the activation curve. In these cases, Application of retigabine partially reversed these effects for the majority of analyzed mutations [5]. However, some mutations of KCNQ2 do not alter significantly the channel properties in term of current intensity, but either the expression of the channel, or even its localization within the neuronal membrane [6]. These alterations are obviously not corrected by retigabine. Moreover, some gain of function mutations have been described in patients with a similar phenotype [7]. Patients carrying such mutations could even be aggravated by retigabine.

\subsection{Estradiol and ARX mutations}

ARX is a transcription factor selectively expressed in neuronal precursors and adult inhibitory interneurons. Several studies have shown that some mutations impaired cell migration. ARX related epilepsy is often severe and of early onset. The 
most common seizure type related to ARX mutation is Epileptic spasms. Using an animal model (mice mutated for ARX), Olivetti et al. showed that a brief estradiol (E2) administration during early postnatal development prevented spasms in infancy and seizures in adult mutants. E2 was ineffective when delivered after puberty or 30 days after birth. They showed that early E2 treatment restored the pool of GABAergic interneurons. Thus, this preclinical study showed for the first time that an early therapeutical intervention may correct or improve a developmental disorder due to an interneuropathy [8].

\subsection{Quinidine and KCNT1 mutations}

Mutations in KCNT1 have been implicated in autosomal dominant nocturnal frontal lobe epilepsy (ADNFLE) and epilepsy of infancy with migrating focal seizures (EIMFS). Using non-neuronal cells with transfection of mutated channels, they showed that KCNT1 mutations implicated in epilepsy cause a marked increase in function and that exposure to quinidine significantly reduces this gain of function for all mutations studied $[9,10]$.

\section{Limits of the precision therapy approach}

The first limitation is that all the pathophysiological consequences of the mutation of a particular gene are not known. For example, the most severe KCNQ2 mutations alter the function of the channel, but also its location in the neuron [5]. The latter alteration is obviously not corrected by retigabine.

Moreover, to date, dozens of genes have been implicated in the EEP. Most frequents are found mutated in less than $20 \%$ of cases, certain genes are described only a few cases. The development of personalized medicine would require for each gene, creating a reliable animal model, validation of preclinical studies and clinical trials, which is not realistic. The discovery of common physiopathological lanes in EEP through fundamental studies on the mechanisms of epilepsy on an immature brain, would be of great help.

Finally, the effectiveness of a particular molecule is tested on its ability to decrease seizure frequency in animal models. However, the severity of EEE is certainly linked to seizures, but not only. It is not impossible that the mechanisms involved in seizure and in the developmental disorder are not the same. In this case, the target chosen to measure the effectiveness of a drug (seizure frequency) would not be good [11].

\section{Disclosure of interest}

The authors declare that they have no competing interest.

\section{Acknowledgements}

We would like to thank all the patients and families. We also want to thank all the clinicians and geneticists that participate to the collaborative project on EOEE.

\section{R E F E R E N C E S}

[1] Auvin S. Should we still consider Dravet syndrome an epileptic encephalopathy? Epilepsy Behav 2014;36:80-1.

[2] Mastrangelo M. Novel genes of early-onset epileptic encephalopathies: from genotype to phenotypes. Pediatr Neurol 2015;53(2):119-29.

[3] Milh M, Boutry-Kryza N, Sutera-Sardo J, Mignot C, Auvin S, Lacoste C, et al. Similar early characteristics but variable neurological outcome of patients with a de novo mutation of KCNQ2. Orphanet J Rare Dis 2013;8:80. http://dx.doi.org/ 10.1186/1750-1172-8-80.

[4] Di Meglio C, Lesca G, Villeneuve N, Lacoste C, Abidi A, Cacciagli $\mathrm{P}$, et al. Epileptic patients with de novo STXBP1 mutations: key clinical features based on 24 cases. Epilepsia 2015;56(12):1931-40.

[5] Orhan G, Bock M, Schepers D, Ilina EI, Reichel SN, Löffler H, et al. Dominant-negative effects of KCNQ2 mutations are associated with epileptic encephalopathy. Ann Neurol 2014;75(3):382-94.

[6] Abidi A, Devaux JJ, Molinari F, Alcaraz G, Michon FX, SuteraSardo J, et al. A recurrent KCNQ2 pore mutation causing early onset epileptic encephalopathy has a moderate effect on $\mathrm{M}$ current but alters subcellular localization of Kv7 channels. Neurobiol Dis 2015;80:80-92. http:// dx.doi.org/10.1016/j.nbd.2015.04.017.

[7] Miceli F, Soldovieri MV, Ambrosino P, De Maria M, Migliore M, Migliore R, et al. Early-onset epileptic encephalopathy caused by gain-of-function mutations in the voltage sensor of Kv7.2 and Kv7.3 potassium channel subunits. J Neurosci 2015;35(9):3782-93.

[8] Olivetti PR, Maheshwari A, Noebels JL. Neonatal estradiol stimulation prevents epilepsy in Arx model of X-linked infantile spasms syndrome. Sci Transl Med 2014;6(220):220ra12. http://dx.doi.org/10.1126/ scitranslmed.3007231.

[9] Bearden D, Strong A, Ehnot J, DiGiovine M, Dlugos D, Goldberg EM. Targeted treatment of migrating partial seizures of infancy with quinidine. Ann Neurol 2014;76(3):457-61. http://dx.doi.org/10.1002/ana.24229.

[10] Milligan CJ, Li M, Gazina EV, Heron SE, Nair U, Trager C, et al. KCNT1 gain of function in 2 epilepsy phenotypes is reversed by quinidine. Ann Neurol 2014;75(4):581-90.

[11] Asinof SK, Sukoff Rizzo SJ, Buckley AR, Beyer BJ, Letts VA, Frankel WN, et al. Independent neuronal origin of seizures and behavioral comorbidities in an animal model of a severe childhood genetic epileptic encephalopathy. PLoS Genet 2015;11(6):e1005347. 